\title{
Could environmental regulations improve the quality of export products? Evidence from China's implementation of a pollution tax
}

\section{Haoyu Kuang}

Shanghai University of Finance and Economics

\section{Yunjun Xiong ( $\sim 251865206 @ q q . c o m$ )}

Shanghai University of Finance and Economics https://orcid.org/0000-0001-7823-8121

\section{Research Article}

Keywords: Environmental regulations, Pollution tax, The quality of export products, Double dividend

Posted Date: March 8th, 2022

DOI: https://doi.org/10.21203/rs.3.rs-1377603/v1

License: (c) (1) This work is licensed under a Creative Commons Attribution 4.0 International License.

Read Full License 


\title{
Could environmental regulations improve the quality of export
}

\section{products? Evidence from China's implementation of a pollution tax} \\ ${ }^{1}$ School of Public Economics and Administration, Shanghai University of Finance and Economics, \\ 200433, Shanghai, China. \\ (1)
}

\begin{abstract}
This study investigates the effect of pollution tax on the quality of export products. As the main environmental regulations for the government to protect the environment, pollution tax have greatly influenced the production behaviour of enterprises. Based on the data of China's pollution tax implementation and industrial enterprise-pollution panel data, we find that the pollution tax have significantly improved the quality of export products, and this conclusion is still valid after a series of robustness tests. Further analysis shows that the increase in the quality of export products originating from the regulated areas could be attributed to enterprise innovation and an increase in the input of intermediate products. The results in this study provide evidence that the central government's environmental policy can realize the double dividend of economic development and environmental protection.
\end{abstract}

Keywords: Environmental regulations; Pollution tax; The quality of export products; Double dividend

JEL Classification: O13, Q56, K23

\section{Introduction}

A continuous deterioration of the environment will bring a series of fatal consequences and affect human survival and development. For example, the London smog incident in 1952 killed 4000 people in just five days (Goldsmith, 1961). As global climate change leads to deterioration, an increasing number of scholars have realized that a balance between economic growth and environmental protection is needed, giving birth to green policy. Environmental laws and regulations are the most common practices in various countries instituted by governments to protect the environment. In China, by the end of 2020, 1,182 local environmental laws and regulations were in force, of which 651 were enacted by districts within cities, and which covered various aspects such as pollution prevention and control, environmental monitoring and comprehensive environmental protection. Effective environmental regulation is not only an important basis for improving the environmental governance ability of local governments but also an institutional guarantee for promoting high-quality economic development.

Environmental pollution is not only an economic problem but also a political one. In China, most environmental protection policies need to be implemented by local governments. Some studies

*Corresponding Author:

Email address: 251865206@qq.com (Y. Xiong). 
believe that Chinese local government officials have incentives to ignore or relax the supervision of environmental pollution and instead devote more energy to the promotion of economic growth in expectation of political promotion ( $\mathrm{Li}$ and Zhou, 2005; Ghanem and Zhang, 2014), such as allocating investment in infrastructure instead of environmental governance (Wu et al., 2014). The environmental policy controlled by local government is considered "bottom-up" environmental regulation. In contrast, "top-down" environmental regulation is supervised by the central government, and local governments need to strictly implement the environmental policies formulated by it. This kind of environmental regulation is more powerful and can affect the production behaviour of enterprises (Sam and Zhang, 2020; Wang et al., 2021). However, most environmental regulations have been implemented by local governments, such as the mayor's strategy for London in Britain and the anti-air pollution law in France. Some studies are carried out on bottom-up environmental regulation, such as the impact of environmental regulation on trade volume (Edengton and Minier, 2003; Levinson and Taylor, 2008; Hering and Poncet, 2014) and employment (Mian and Sufi, 2014; Grey and Shadbegian, 2014; Zhong et al., 2021). Considering that all countries have gradually implemented "top-down" environmental policies against the backdrop of global sustainable development, it is particularly important to study the impact of "topdown" environmental regulation on the quality of enterprises' export products.

In this study, we consider the policies of the pollution tax implemented in China in 2003 and match the data of Chinese industrial enterprises and enterprise pollution emissions to investigate the impact of environmental regulation on the quality of enterprise export products. As the first topdown environmental regulation policy in China, the pollution tax mainly has an impact on polluting enterprises, which provides a quasi-natural experiment for our research. We use the differences-indifferences (DID) method to identify the quality of enterprises' export products before and after the implementation of the pollution tax. Our empirical findings suggest a potential causality between the implementation of the pollution tax policy and the quality of export products. In addition, we further find that the increase in the quality of export products originating from the regulated areas can be attributed to enterprise innovation and an increase in the input of intermediate products.

It is worth noting that in the existing research, scholars believe that environmental regulation mainly affects enterprises through the "compliance cost effect" (Christainsen and Haveman, 1981; Levinson and Taylor, 2008) and "innovation compensation effect" (Porter and Linde, 1995; Peuckert, 2014; Jorge et al., 2015; Cao et al., 2020). The "top-down" environmental regulations implemented throughout the country may be different. Since "top-down" environmental regulation is stricter for polluting enterprises, the "compliance cost effect" may be too large for some enterprises that produce low-quality products, leading them to withdraw from the market (Deily and Grey, 1991; Jefferson et al., 2013; Hering and Poncet, 2014), thereby enabling the remaining enterprises to obtain greater market share. Whether or not the input of intermediate products has affected the quality of export products of enterprises is also one of the key issues we address.

Our research mainly complements the existing literature in the following ways. First, as the first top-down environmental regulation policy, the pollution tax helps us to differentiate the impact of these environmental regulation from regulations implemented by local governments, which supplements the study of environmental regulation. Second, we strived to match the pollution database and customs database of Chinese enterprises and used the DID model to provide evidence for the central government for implementing environmental taxes and promoting quality exports, 
which also provides a reference for the central governments of other countries to implement environmental supervision.

The rest of the paper is structured as follows. Section 2 provides background information. Section 3 describes the data, variables and empirical specifications. Section 4 presents the baseline results and robustness results. Section 5 presents the mechanism analysis, and Section 6 concludes.

\section{Background and theoretical analysis}

\subsection{Background}

China's environmental regulation could be traced back to 1956. The central government introduced the slogan of "recycling waste", but related policies were relatively scattered and lacked specific environmental management procedures and laws, so comprehensive requirements of environmental protection were not achieved. After China's reform and opening up, environmental problems became increasingly serious. The Chinese central government began to write environmental protection into the constitution, establishing environmental protection as a basic national policy, and gradually began an environmental regulation policy. However, China is a highly centralized country, and the central government has absolute rights in appointing and promoting local government officials according to their political performance. Based on a growth-oriented strategy, local governments had adopted economic growth as their main goal. The central government had given local governments more rights to create environmental protection policies, which led to many "bottom-up" environmental regulation policies in the early stages of environmental regulation. The excessive consumption of resources by China's extensive economic growth has led to China's environmental pollution problem becoming more serious.

Since the start of this century, with the improvements of economic development, environmental protection has gradually become an issue highly valued by the central government. Following the 16th National Congress of the Communist Party of China in 2002, China's development strategy adopted the "Outlook (View) of Scientific Development", replacing the previous growth-oriented strategy. In July 2003, the central government officially issued pollution tax documents and strictly required local governments to implement them. This document clearly notes the pollution tax (fee) standards for waste gas, wastewater and solid waste, imposes environmental taxes on enterprises that exceed the pollution discharge standards, and punishes severely polluting enterprises by shutting them down. In addition, local pollution data has become an important criterion for higherlevel officials' assessments. This policy has greatly increased the supervision and law enforcement of environmental pollution by local governments. At this stage, the pollution fee has already become a specific tax, and the rights are in the hands of the central government. This policy also began a precedent of top-down environmental regulation.

To illustrate the effect of the policy, we collected data on pollution emissions during the policy period from the official website of the Ministry of Ecology and Environmental of China. Fig. 1 show the emissions of major pollutants. The emissions of industrial wastewater, industrial solid waste, industrial waste gas, and sulfur dioxide have shown a decreasing trend year by year. This suggests that enterprises have significantly reduced the emission of pollutants after the central government implemented the pollution tax, and the pollution tax played a significant role in reducing pollution and protecting the environment. 


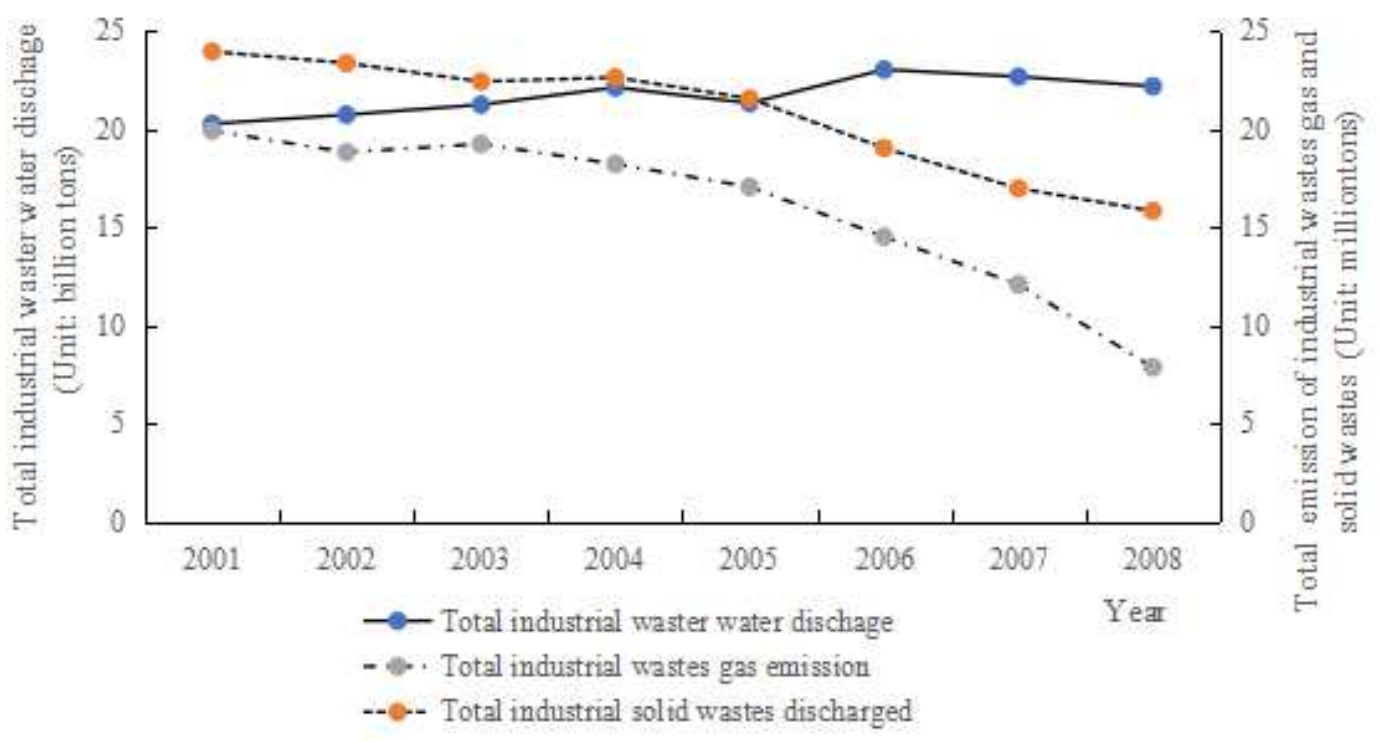

Fig. 1. Environmental protection in China from 2001 to 2008

Data source: China Statistical Yearbook

\subsection{Theoretical analysis}

Generally, government environmental regulation mainly affects the export behaviour of enterprises by stimulating enterprise innovation and promoting the growth of enterprise input of intermediate products, promoting enterprises to increase the added value of export products, and then improving the quality of product exports.

\section{Enterprise Innovation Incentive}

The government's environmental control can promote the export behaviour of enterprises through the "innovation compensation effect" (Melitz, 2003). Specifically, it is manifested in two aspects. On the one hand, with the strengthening of government environmental regulations, companies are facing more pollution costs, leading to an increase in overall production costs. In this case, companies will take the initiative to carry out technological changes, improve energy efficiency, and reduce pollution emissions per unit of product for the purpose of "reducing pollution and increasing efficiency"; on the other hand, the enterprise technology research and development part will increase investment in enterprise innovation research and development, carry out more product technology innovations to improve product competitiveness, and compensate for the costs caused by the collection of pollution taxes. Technological innovation increases international competitiveness (Porter et al., 1995). In summary, as the government strengthens environmental regulations, companies will increase investment in $\mathrm{R} \& \mathrm{D}$ for technological innovation, which is also conducive to improving corporate productivity and value-added exports and ultimately improving the quality of corporate export products.

Increase of Enterprise Intermediate Goods Input

After the government strengthens environmental regulations, companies need to pay more pollution taxes to the government or invest funds to deal with pollution. These actions will increase the production cost of the enterprise and produce a "crowding out effect" on the enterprise's production investment. (Cole et al., 2005). Under the premise that enterprises are facing fierce 
competition in the market environment, to expand market share and increase economic returns, they can only expand the scale of exports, increase the added value of export products, and "improve quality and efficiency." Intermediate product input is an important indicator to measure the production of enterprises. The growth of intermediate product input will bring higher product added value to the enterprise and will undoubtedly increase the quality of export products. Enterprises facing government environmental regulations will increase their investment in intermediate products to produce more value-added products, which will have a positive impact on corporate exports, thereby expanding their share in the international market and increasing exports. These advantages make up for the cost of the pollution tax.

\section{Data and Research Design}

\subsection{Data source}

This study mainly involves three datasets. The first is the Chinese industrial enterprises database. Industrial enterprise databases are the most widely covered microenterprise databases in continuous surveys. This database contains the internal information of all enterprises with a turnover of more than 5 million Yuan, including enterprise size, personnel composition, capital ratio, etc. The second is the Chinese enterprise pollution database. This database reflects the pollution emissions of Chinese enterprises in detail, including industrial wastewater, waste gas, dust and other emissions. The third is the Chinese export customs database. This database mainly includes export and product data of related enterprises. In addition, the database also provides information such as business emails and phone numbers, which helps to further achieve accurate matching of the three types of data.

Product export quality: We refer to Hallak and Sivadasan's (2009) and Khandelwal et al.'s (2013) postinference method to measure the quality of export products. The quantity of export product is set as follows:

$$
Q_{\text {imgt }}=p_{\text {imgt }}{ }^{-\sigma} \Omega_{\text {imgt }}{ }^{-\sigma} \frac{E_{m t}}{P_{m t}}
$$

Take the logarithm of the above formula:

$$
\ln Q_{\text {imgt }}=\ln E_{m t}-\ln P_{m t}-\sigma \ln p_{\text {imgt }}+\mu_{\text {imgt }}
$$

where $\ln E_{m t}-\ln P_{m t}$ depends on the time and export destination country and $\mu_{i m g t}=(\sigma-1) \ln \Omega_{i m g t}$ contains the quality information of the exported products. If we simply perform OLS regression on this formula, we will ignore the differences in product types and the endogenousness of prices, leading to biases in the estimation results. Furthermore, we refer to the practice of Khandelwal (2010), add the actual GDP of each province that represents market demand, and select the average price as an instrumental variable (Nevo, 2001), and the expression formula for the export quality of product is:

$$
\text { quality }_{\text {imgt }}=\overline{\ln \Omega_{\text {imgt }}}=\frac{\overline{\mu_{i m g t}}}{\sigma-1}=\frac{\ln Q_{i m g t}-\ln \overline{Q_{i m g t}}}{\sigma-1}
$$


Furthermore, to facilitate comparison, the above formula is standardized:

$$
\text { rquality }_{\text {imgt }}=\frac{\text { quality }_{\text {imgt }}-\min \text { quality }_{\text {imgt }}}{\max \text { quality }_{\text {imgt }}-\min \text { quality }_{\text {imgt }}}
$$

Among them, max and min represent the maximum and minimum values of all companies at the product level, respectively. Finally, the quality of an enterprise's export product weighted by export value is expressed as:

$$
\text { quality }_{\text {imgt }}=\frac{v_{\text {imgt }}}{\sum_{i m g t \in \Phi} v_{i m g t}} \text { rquality }_{\text {imgt }}
$$

where $v_{\text {imgt }}$ represents the value of the export product of enterprise to country in year; $\Phi$ represents the set of export products of enterprise to all countries in year.

Pollution tax: Since the pollution tax is implemented simultaneously throughout the country, it is difficult to further identify whether the enterprise is affected by this policy. In fact, enterprises with high pollution are more vulnerable to this policy. Therefore, we discern whether the enterprise is treated according to how its pollution emissions relate to the median of all enterprises. If the emission intensity of an enterprise is greater than the median, it will enter the treatment group, and if the emission intensity is less than or equal to the median, it will enter the control group. There were 32,035 samples in 2000-2008, including 16,163 samples in the treatment group and 15,872 samples in the control group.

Other enterprise-level data mainly include enterprise size (size), number of employees $(\operatorname{lnL})$, enterprise age (age), capital concentration (lnkl), asset-liability ratio (lev), financing constraints (finance), government subsidy intensity (sub), corporate profit rate (profit), capital output ratio (kc) and per capita wages (lnwage). These variables are the key factors affecting the export quality of enterprises. Table 1 reports the summary statistics of the above dependent variable, independent variable, control variables and mechanism analysis variables.

\section{Table 1}

Summary statistics

\begin{tabular}{cccccc}
\hline Variable code & Observations & Mean & Standard deviation & Min & Max \\
\hline quality & 32035 & 0.762 & 0.127 & 0 & 1 \\
treat & 32035 & 0.504 & 0.500 & 0 & 1 \\
post & 32035 & 0.571 & 0.495 & 0 & 1 \\
size & 31995 & 11.648 & 1.498 & 0 & 18.96 \\
lnL & 27960 & 6.185 & 1.184 & 0 & 11.31 \\
age & 32004 & 16.072 & 30.598 & 0 & 2008 \\
lnkl & 27909 & 4.314 & 1.261 & -3.40 & 10.91 \\
lev & 31995 & 0.574 & 0.291 & -0.28 & 9.84 \\
finance & 31947 & 0.036 & 1.649 & -287.25 & 62.43 \\
sub & 26237 & 0.003 & 0.063 & -0.18 & 7.60 \\
profit & 31995 & 0.197 & 27.955 & -2.37 & 5000 \\
kc & 28405 & 3.307 & 449.872 & 0 & 75820 \\
lnwage & 25769 & 2.617 & 0.700 & -5.20 & 7.53 \\
\hline
\end{tabular}

Notes: This table gives the summary statistics of the main variables. Please refer to Table An in the Appendix for definitions and sources of those variables. 


\subsection{Empirical strategy}

We use a differences-in-differences (DID) regression model on the full sample to estimate the effects of a pollution tax on the quality of export products. As an exogenous policy, a pollution tax brought exogenous changes to the quality of export products of the treated enterprises, which provides us with a unique quasi-natural experiment. The DID model helps us identify the causal relationship between pollution taxes and the quality of export products. The specific regression equation is set as follows:

$$
\text { quality }_{i t}=\alpha+\text { Btreat }_{i}{ }^{*} \text { post }_{t}+\gamma \text { controls }_{i t}+v_{i}+\lambda_{t}+\varepsilon_{i t}
$$

where quality $y_{i t}$ represents the quality of the enterprise's export products and treat $_{i}$ is a dummy variable used to describe the pollution tax. It will be coded 1 if enterprise $i$ is treated and 0 otherwise. post $t_{t}$ is a time dummy; it will be coded 1 if the year is after 2003 and 0 otherwise.

controls $_{i t}$ denotes a series of control variables that may affect the quality of an enterprise's export products, $\lambda_{t}$ and $v_{i}$ are year fixed effects and city fixed effects, respectively, and $\varepsilon_{i t}$ is the error term. The coefficient $\beta$ captures the treatment effect of the pollution tax on the quality of enterprises' export products. If $\beta$ is significantly positive, it indicates that the pollution tax has significantly promoted the quality of the enterprise's export products.

\section{Main results}

\subsection{Baseline results}

Starting with the DID of the baseline, we estimate Eq. (1) using customs-industry-enterprisepollution matching panel data. Table 2 presents our baseline results obtained both with and without adding control variables. Estimates are separately reported in Columns (1) and (2). The estimated coefficients of interest are highly significant. The results in Table 2 show that pollution taxes have a significantly positive effect on the quality of enterprises' export products. Therefore, this article confirms that environmental regulations can serve as an exogenous driving force for the quality improvement of China's export products.

\section{Table 2}

The impact of environmental regulations on the quality of export products

\begin{tabular}{ccc}
\hline Variable & $(1)$ & $(2)$ \\
\hline \multirow{2}{*}{ Treat*post } & $0.0071^{* * *}$ & $0.0118^{* * *}$ \\
& $(0.0027)$ & $(0.0035)$ \\
size & & $0.0180^{* * *}$ \\
& & $(0.0030)$ \\
$\operatorname{lnL}$ & & $0.0111^{* * *}$ \\
& & $(0.0034)$ \\
\hline
\end{tabular}




\begin{tabular}{|c|c|c|}
\hline lev & & $\begin{array}{c}0.0112 * * \\
(0.0051)\end{array}$ \\
\hline finance & & $\begin{array}{c}0.0044 * * * \\
(0.0016)\end{array}$ \\
\hline age & & $\begin{array}{c}-0.0001 * \\
(0.0008)\end{array}$ \\
\hline lnwage & & $\begin{array}{l}0.0036^{*} \\
(0.0021)\end{array}$ \\
\hline sub & & $\begin{array}{c}-0.0151 * * \\
(0.0065)\end{array}$ \\
\hline profit & & $\begin{array}{c}0.0237 * * * \\
(0.0082)\end{array}$ \\
\hline $\mathrm{kc}$ & & $\begin{array}{l}-0.0010 \\
(0.0011)\end{array}$ \\
\hline Individual fixed-effect & YES & YES \\
\hline Year fixed-effect & YES & YES \\
\hline Observations & 30462 & 20145 \\
\hline R-squared & 0.56 & 0.54 \\
\hline
\end{tabular}

\subsection{Dynamic effect and parallel trend test}

The accuracy of the DID estimation results depends on whether the control group and the treatment group satisfy parallel trend conditions. According to the research setting of this article, the parallel trend test requires that the change trend of export product quality of enterprises in the treatment group and the control group should be similar before the implementation of the pollution tax policy. This article uses the event analysis method for verification. To this end, this article draws on the practice of Jacobson (1993) and sets the econometric regression model as follows:

$$
\text { quality }_{i t}=\alpha+\beta_{k} \sum_{k \geq 3}^{3} \text { treat }_{i} * D_{t}^{k}+\gamma \text { controls }_{i t}+v_{i}+\lambda_{t}+\varepsilon_{i t}
$$

where $D_{t}^{k}$ is an event-time dummy variable with a value of 0 or 1 . When $k>0$, it takes 1 for

the kth year before the policy shock and 0 otherwise; when $k<0$, it takes 1 for the kth year after the policy shock and 0 otherwise; and when $k=0$, it is set to 1 and 0 otherwise. For the convenience of analysis, the case of $k \geq 3$ is regarded as $k=3$, that is, it corresponds to 3 years after the policy shock takes place as 1 and 0 otherwise. At this time, the regression coefficient represents the difference between the treatment group and the control group one year before the policy shock.

Fig. 3 presents the test results of parallel trends. pre_3-pre_2 indicates the estimated value corresponding to the three years before the policy occurred to the first two years of the policy, current indicates the estimated value in the year when the policy occurred, and post_1-post_3 indicates the estimated value of the coefficient from one year to the next five years after the policy occurred. pre_3-pre_2 fluctuates approximately 0 , corresponding to a wide $95 \%$ confidence interval and crossing 0 , indicating that there is no significant difference between the treatment group and the control group compared to the year before the policy occurred. The assumption of parallel trends in this article is satisfied. In addition, it can be seen that in the years after the implementation of the 
policy, the trend of the graph is upwards, which further verifies the benchmark regression results of this article.

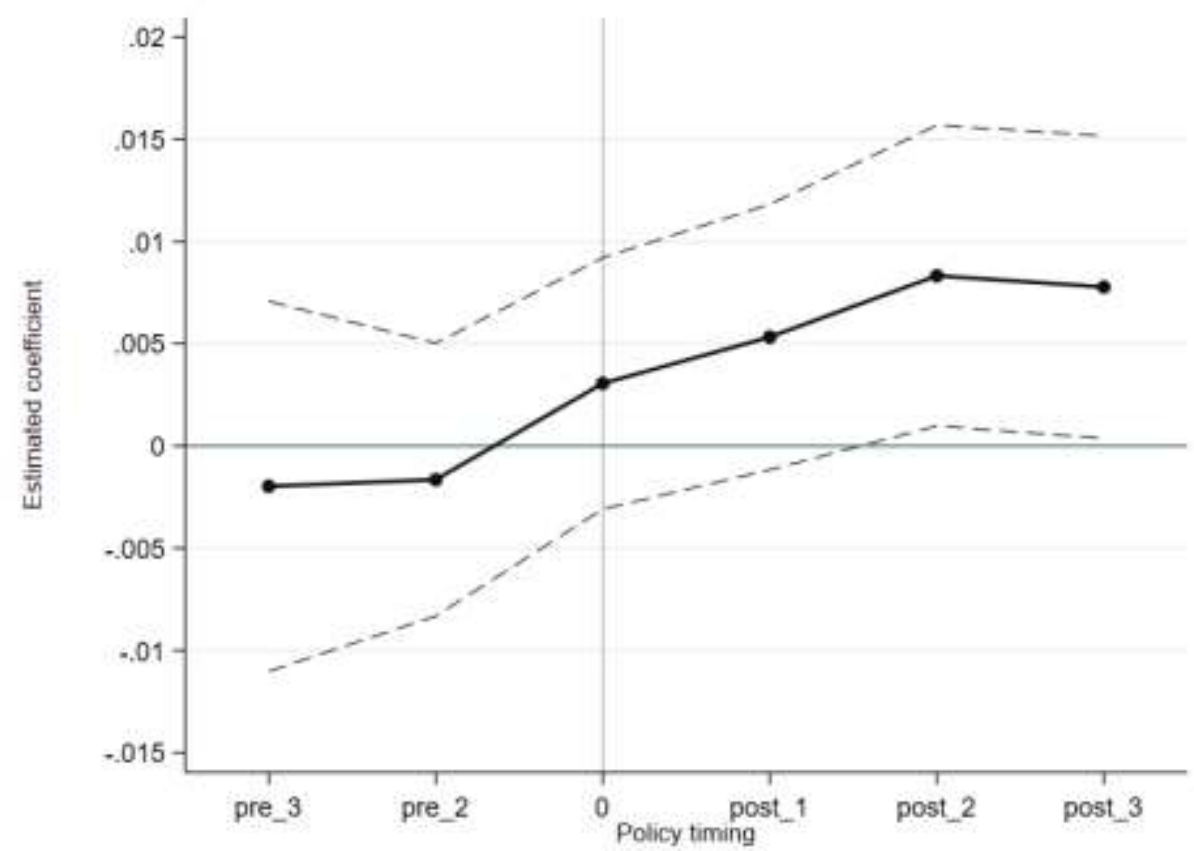

Fig. 2. Parallel Trend Test Chart

Notes: We sets $k=-1$ as the base period. The solid line plots the point estimation coefficient, and the dashed lines denote the $95 \%$ confidence interval.

\subsection{Robustness test}

Although the previous parallel trend test and DID results steadily show that environmental regulations have significantly improved the quality of export products of enterprises, it is still impossible to completely eliminate endogenous problems caused by factors such as measurement errors and enterprises' self-selection. To determine the credibility of the research results, we conducted a series of robustness tests.

Placebo test

This article draws on the research design ideas of Liu and Mao (2019) by randomly assigning corporate environmental emission intensity and constructing a "false" treatment group and a control group for placebo testing. The specific process is as follows. First, randomly group each enterprise; second, determine the pollution emission intensity on the basis of random grouping; finally, use the intensity DID model to estimate and obtain the estimated coefficient. The above process was repeated 500 times to obtain a placebo test chart (see Fig. 4). The curve is the kernel density curve of the estimated coefficient, the scattered points represent the $\mathrm{p}$ statistic corresponding to the estimated coefficient, and the red vertical line on the right is the true estimate of the quality of the enterprise' s export products from the above government environmental regulations. From the results in the figure, it can be seen that the estimated coefficients of the placebo variables are mainly concentrated near zero, and the absolute majority of $\mathrm{p}$ statistic values are greater than 0.1 ; the true estimated value is an obvious outlier in the placebo, indicating that the implementation effect of the policy is comparable to that of the placebo. The variables are significantly different. Government environmental regulations are indeed the reason for promoting the quality of export 
products of enterprises.

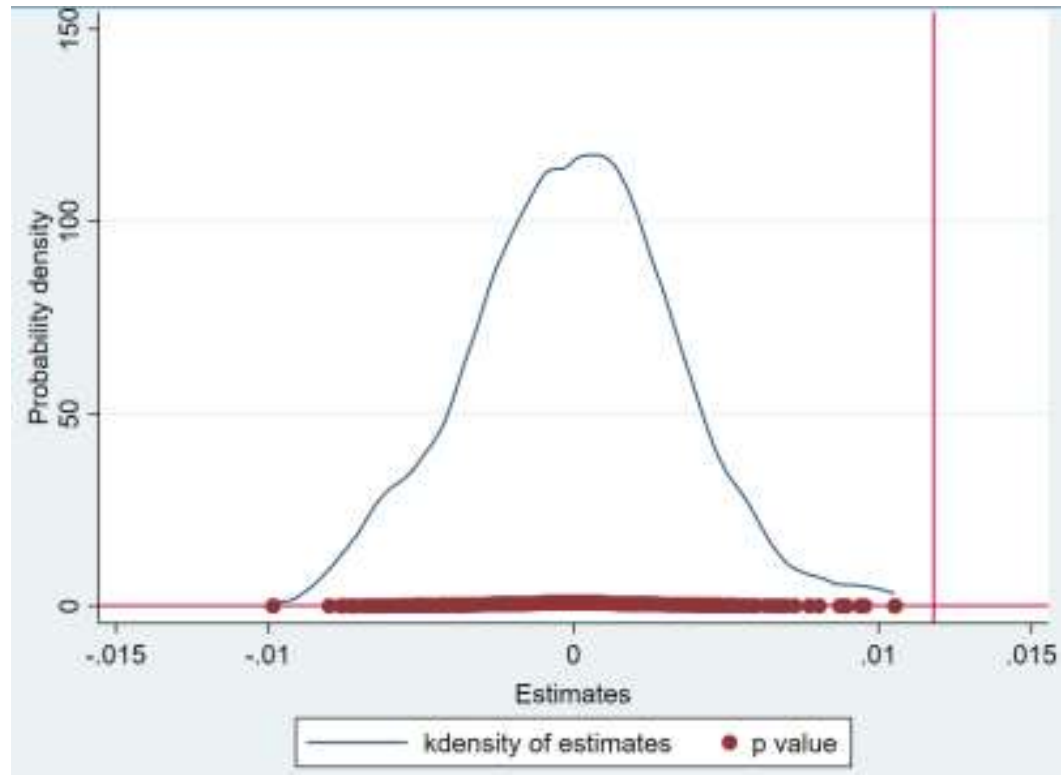

Fig. 3. Placebo test

Robustness test of substitution variables.

There are many methods to measure the quality of product exports. We use a mainstream method in the benchmark regression. At the same time, we consider whether the conclusions of the article will change due to changes in variables. For this reason, we use different methods to substitute variables. We use two tests to verify the robustness of the results: one uses the logarithm of the total export value to replace the quality of export products; the other uses the total export value to measure the quality of product exports; the inspection results are shown in Columns (1) and (2) in Table 3. In addition, the coefficient value of the policy interaction term has risen, and both can maintain a significant level; it shows that the government's environmental regulation policy has a promotion effect on the export value and total export value of enterprises, and to a certain extent the policy supports the effect of improving the quality of export products of enterprises. Considering that the outliers in product export quality may have an impact on the regression results, we performed a $1 \%$-level tailing treatment on the explained variables and then performed the regression again. The results are shown in Column (3) in Table 3, and we can see the exclusion. The coefficient change after the outlier influence is basically not large, and it is also significant at the $1 \%$ level; considering that the intensity DID model is used in this article, the core explanatory variable intensity grouping may affect the robustness of the conclusion, so we determine the intensity based on the average value. After the redivision of the treatment group and the control group, the regression results are shown in Column (4) of Table 3. Although the regression results are still positive after changing the intensity grouping, they are indeed not significant at all, which proves that use of the median grouping is reasonable. In summary, after conducting a series of alternative tests on the explained variables and core explanatory variables, the conclusion that government environmental regulations promote the quality of Chinese enterprises' export products is still valid.

\section{Table 3}

Robustness test of substitution variables. 


\begin{tabular}{ccccc}
\hline Variable & $(1)$ & $(2)$ & $(3)$ & $(4)$ \\
\hline Treat*post & $0.220^{* * *}$ & $0.1433^{*}$ & $0.0115^{* * *}$ & 0.0041 \\
Control variables & $(0.0531)$ & $(0.0832)$ & $(0.0004)$ & $(0.0027)$ \\
Individual fixed effect & YES & YES & YES & YES \\
Year fixed effect & YES & YES & YES & YES \\
Observations & YES & YES & YES & YES \\
R-squared & 20145 & 13677 & 20145 & 20145 \\
\hline
\end{tabular}

Notes: ${ }^{*}, * *$, and $* * *$ indicate statistical significance at the $10 \%, 5 \%$, and $1 \%$ levels, respectively. The individual-

321 level clustered standard errors are reported in parentheses.

322 Exclude the impact of corporate withdrawal and value-added tax transition policies.

Relevant studies have shown that enterprise entry and exit are relatively common phenomena. If there is a significant difference in emission intensity between the remaining operating companies and the exiting companies, then the exit of the enterprise may lead to sample selectivity issues. For this reason, in considering the impact of government environmental regulations on the quality of export products of enterprises, it is necessary to further explore the impact of enterprise withdrawal on the results of benchmark regression. Columns (1) and (2) in Table 4 show that after excluding the exit of the enterprise, the aforementioned basic conclusion has not changed regardless of whether the control variable is added or there is no control variable.

After 2003, when the new central leadership came to power, China continued to adhere to the development path characteristic of socialism. At the same time, under the guidance of the "Scientific Outlook on Development", the country began to pay attention to the protection of the ecological environment while focusing on economic construction. Additionally, to promote coordinated regional development and reform of the economic system, the central government launched a pilot value-added reform in the three northeastern provinces (Heilongjiang, Jilin and Liaoning) in 2004, allowing input deductions for fixed assets purchased by enterprises. This policy reduces the production cost of enterprises; some scholars believe that the value-added tax transformation policy will have an impact on the export probability, type and quantity of enterprises ( $\mathrm{Liu}$ and $\mathrm{Lu}, 2015$ ), which will also have a direct impact on the quality of product exports. To further enhance the credibility of the research results of this article, this article will consider the impact of the interference of the value-added tax transition policy and will not consider the enterprises in the three northeastern provinces in 2004 and after. At the same time, the samples after 2007 are excluded. The regression results are shown in Columns 4 (3) and (4). Column (3) is the estimated result after excluding samples of enterprises in the VAT transition area, and the coefficient is still significantly positive; Column (4) adds enterprise-level control variables based on Column (3), adding the results after the control variables are significant at the $1 \%$ level. Even after considering the impact of the value-added tax transition policy, environmental regulations still have a significant role in promoting the quality of Chinese enterprises' export products.

Based on the above analysis, the core results of this article are still very stable after excluding the impact of corporate withdrawal and value-added tax transformation policies, which again confirms the reliability of the results of this article.

355 Exclude the impact of corporate withdrawal and value-added tax transition policies. 


\begin{tabular}{ccccc}
\hline Variable & \multicolumn{2}{c}{ Business exit } & \multicolumn{2}{c}{ VAT transformation } \\
& $(1)$ & $(2)$ & $(3)$ & $(4)$ \\
\hline Treat*post & $0.0105^{* * *}$ & $0.0139^{* * *}$ & $0.0064^{* *}$ & $0.0119^{* * *}$ \\
Control variables & $(0.0030)$ & $(0.0038)$ & $(0.0028)$ & $(0.0037)$ \\
Individual fixed effect & YES & YES & YES & YES \\
Year fixed effect & YES & YES & YES & YES \\
Observations & YES & YES & YES & YES \\
R-squared & 23181 & 14748 & 25087 & 17124 \\
\hline
\end{tabular}

Notes: $* * *$, and $* * *$ indicate statistical significance at the $10 \%, 5 \%$, and $1 \%$ levels, respectively. The individuallevel clustered standard errors are reported in parentheses.

\subsection{Analysis of heterogeneity}

In the previous section, the average treatment effect (ATT) of the government's environmental regulations on the quality of export products of enterprises was investigated, and a series of robustness tests were carried out. However, the heterogeneity of enterprises, industries and regions that may affect the quality of product exports has not yet been distinguished. Next, this article will discuss in depth the heterogeneous influence of environmental regulations on the quality of enterprise export products based on heterogeneity at the enterprise level, heterogeneity at the regional level and heterogeneity at the industry level.

\section{Heterogeneity of enterprise characteristics}

Since 2003, China has accelerated the process of marketization while state-owned enterprises have also carried out a series of reforms, and China' s private economy has subsequently developed rapidly. What is the impact of government environmental regulations on the quality of export products of enterprises between state-owned enterprises and nonstate-owned enterprises? It is heterogeneous and will be discussed in this section.

Columns (1) and (2) in Table 5 show that the policy interaction term (Treat*post) of stateowned enterprises is not significant, and Tables (3) and (4) show that the estimated coefficients of the cross-terms of nonstate-owned enterprise dummy variables are significantly positive. This result shows that the government's environmental regulations have a significant positive impact on the quality of export products of nonstate-owned enterprises, but they have almost no impact on the quality of export products of state-owned enterprises. This result also objectively shows that stateowned enterprises are less affected by government environmental regulations. The possible reasons for this discrepancy are as follows: On the one hand, state-owned enterprises have a greater political connection with the government, and the management of state-owned enterprises can easily communicate with local governments as administrative leaders. Local governments are often unwilling to offend state-owned enterprises, so in terms of environmental law enforcement and fines law enforcement is differentiated between state-owned and nonstate-owned enterprises, resulting in state-owned enterprises being less affected by environmental regulations and having no incentive to innovate and expand exports (Boubakri et al., 2008; Zhou et al., 2017). On the other hand, compared with nonstate-owned enterprises, state-owned enterprises often need to consider economic and social effects and implement environmental protection policies more strongly, so there is no serious environmental pollution; however, nonstate-owned enterprises simply pursue economic benefits and often ignore protection of the environment. Under the strict environmental 
regulations implemented by the government, the interests of nonstate-owned enterprises will be harmed to a greater extent, so they are motivated to promote enterprise innovation and increase the added value of products to improve export quality, expand export scale, gain competitive advantage, and make up for environmental regulations and prevent loss of welfare.

Table 5

Heterogeneity of enterprise characteristics

\begin{tabular}{ccccc}
\hline Variable & \multicolumn{2}{c}{ State-owned enterprise } & \multicolumn{2}{c}{ Nonstate-owned enterprise } \\
& $(1)$ & $(2)$ & $(3)$ & $(4)$ \\
\hline Treat*post & 0.0082 & 0.0171 & $0.0054^{*}$ & $0.0091^{* *}$ \\
Control variables & $(0.0080)$ & $(0.0121)$ & $(0.0029)$ & $(0.0037)$ \\
Individual fixed effect & YES & YES & YES & YES \\
Year fixed effect & YES & YES & YES & YES \\
Observations & YES & YES & YES & YES \\
R-squared & 6053 & 4160 & 23957 & 15516 \\
& 0.48 & 0.44 & 0.58 & 0.59 \\
\hline
\end{tabular}

Notes: *,*, and *** indicate statistical significance at the $10 \%, 5 \%$, and $1 \%$ levels, respectively. The individuallevel clustered standard errors are reported in parentheses.

Heterogeneity in different regions

The development gaps between China's regions are large and are manifested in the significant differences in the level of economic development, infrastructure construction, and political and business environment in the western region and the central and eastern regions. In 2002, the western region accounted for approximately $70 \%$ of the country's total area, but its GDP only accounted for $15 \%$ of the country's total, which represents a significant gap with the eastern region. In 2000, the Chinese government proposed the "China's Western Development Policy" plan and adopted a series of policy support measures for the western region. Considering the heterogeneous impact of environmental regulations on the export products of enterprises in areas with different economic development conditions and development levels, this article divides the sample into eastern regions and central and western regions. Columns (1) and (2) in Table 6 reflect the regression results in the western region. The regression results in the western region are not significant; Columns (3) and (4) show the regression results in the eastern and central regions, and the results indicate that the estimated coefficient of the intersection of environmental regulations and the dummy variables in the eastern and central regions is significantly positive. Compared with the western regions, environmental regulations have a significant effect on the quality of export products of enterprises in the eastern and central regions. The reason may be that compared with the western region, enterprises in the central eastern region face a better development environment, a relatively higher level of economic development, and stronger capabilities in technological innovation and product upgrading. Under the influence of government environmental regulations, the eastern region enterprises in the central region can take the lead in transforming their economic development mode, and their exported products may have higher quality because of the use of higher technology or added value. This also illustrates the need for the Chinese government to implement the China Western Development Policy and promote coordinated regional development.

\section{Table 6}

Heterogeneity in different regions. 


\begin{tabular}{ccccc}
\hline Variable & \multicolumn{2}{c}{ Western Region } & \multicolumn{2}{c}{ Nonwestern regions } \\
& $(1)$ & $(2)$ & $(3)$ & $(4)$ \\
\hline Treat*post & -0.0126 & 0.0001 & $0.0076^{* * *}$ & $0.0117^{* * *}$ \\
Control variables & $(0.0157)$ & $(0.0192)$ & $(0.0028)$ & $(0.0035)$ \\
Individual fixed effect & YES & YES & YES & YES \\
Year fixed effect & YES & YES & YES & YES \\
Observations & YES & YES & YES & YES \\
R-squared & 1934 & 1284 & 28528 & 18861 \\
\hline
\end{tabular}

Notes: $* * *$, and $* * *$ indicate statistical significance at the $10 \%, 5 \%$, and $1 \%$ levels, respectively. The individuallevel clustered standard errors are reported in parentheses.

Distinguish between different industries

Considering that different industries have large differences in the input and output of production factors, there will also be heterogeneity in environmental pollution emissions and the quality of enterprise product exports. Generally, light industry produces less pollution and reflects the degree of government environmental regulations. The heavy chemical industry itself is a polluting enterprise, subject to strict government environmental regulations and supervision, and more sensitive to changes in pollution charges. In view of the classification of light and heavy industries in the sample data in the industrial enterprise database, we combined the different light industry and heavy chemical industries in the data to form a unified light industry and heavy industry classification sample and then regressed separately. The results are shown in Table 8. Columns (1) and (2) are the regression results of the sample of light industry enterprises, which can be seen to be nonsignificant; Columns (3) and (4) are the regression results of the sample of heavy industry enterprises, and both benchmark regression and added control variable regression results are significantly positive at the $5 \%$ level. These results are not difficult to explain. On the one hand, heavy industry is a polluting industry and is very sensitive to government environmental regulations. After the government implemented the pollution tax policy, there were incentives to carry out technological innovation and product upgrades to increase the added value of products. On the other hand, heavy industries are often capital and technology-intensive enterprises, facing higher export demand and motivation. Under pressure from rising domestic taxes and fees, enterprises expand export demand and gain foreign customers through higher product quality. They recognize the need to obtain greater overseas profits to make up for the cost burden caused by the increase in domestic environmental protection taxes.

\section{Table 7}

Distinguish the analysis of different types of industries

\begin{tabular}{ccccc}
\hline Variable & \multicolumn{2}{c}{ Light industry } & \multicolumn{2}{c}{ Heavy industry } \\
& $(1)$ & $(2)$ & $(3)$ & $(4)$ \\
\hline Treat*post & 0.0025 & 0.0058 & $0.0154^{* *}$ & $0.0231^{* * *}$ \\
& $(0.0044)$ & $(0.0053)$ & $(0.0065)$ & $(0.0078)$ \\
Control variables & YES & YES & YES & YES \\
Individual fixed effect & YES & YES & YES & YES \\
Year fixed effect & YES & YES & YES & YES \\
Observations & 11105 & 8604 & 7792 & 6004 \\
R-squared & 0.58 & 0.59 & 0.50 & 0.50 \\
\hline
\end{tabular}
level clustered standard errors are reported in parentheses. 


\section{Underlying mechanisms}

The above content, through rich causal identification and various robustness tests, shows that government environmental regulations have significantly improved the quality of export products of enterprises, so what channel mechanism does environmental regulation use to improve the quality of export products of enterprises? In-depth research on this topic is helpful to deeply understand the internal connection between government environmental regulations and the quality of export products of enterprises. Through the analysis of the second part of this article, we know that environmental regulation specifically affects the quality of export products of enterprises by changing the input of enterprise innovation and enterprise intermediate products. In this part, we specifically examine the transmission mechanism of environmental regulations on the quality of export products of enterprises and analyse how it affects the quality of export products of enterprises.

\subsection{Enterprise Innovation Incentive}

According to the analysis of the previous mechanism, government environmental regulations have increased the environmental costs of enterprises. To reduce environmental emissions, enterprises increase R\&D investment, which will increase the added value of products and the quality of exports. To investigate this mechanism, this paper uses the logarithm of the enterprise's $R \& D$ expenditure as the explained variable to regress the DID variable, and the regression results are reported in Table 9. The estimated value of the DID coefficient passed the significance test at a significance level of $1 \%$, indicating that after the government strengthened environmental regulations, R\&D investment, an important measure of corporate innovation, increased significantly. To further test the reliability of the conclusions, we use the number of enterprise patent applications as an indicator to measure enterprise innovation for re-examination. Enterprise patent indicators include "number of invention patent applications", "number of utility model patent applications" and "number of appearance patent applications". We add up the three types of patents to obtain the total number of patent applications of the enterprise. Then, we add 1 to the number of patent applications, take the logarithm, and obtain the regression result, as shown in the second column of Table 9. After the total number of patents is used to measure enterprise innovation, the regression result is still significant at the $1 \%$ level. The above fully demonstrates that the government's environmental regulations have promoted enterprises to increase R\&D investment, increase the added value of products, and ultimately improve the quality of their export products.

\section{Table 8}

Analysis of the Impact Mechanism of Enterprise R\&D Investment

\begin{tabular}{ccc}
\hline Variable & $\ln ($ R\&D expenses) & $\operatorname{Ln}($ Total number of patents +1$)$ \\
& $(1)$ & $(2)$ \\
\hline Treat*post & $1.1721^{* * *}$ & $0.1121^{* * *}$ \\
Control variables & $(0.1100)$ & $(0.0191)$ \\
Individual fixed effect & YES & YES \\
Year fixed effect & YES & YES \\
Observations & YES & 20145 \\
R-squared & 20145 & 0.56 \\
\hline
\end{tabular}

Notes: ${ }^{*}, * *$, and $* * *$ indicate statistical significance at the $10 \%, 5 \%$, and $1 \%$ levels, respectively. The individuallevel clustered standard errors are reported in parentheses. 


\subsection{Increase of Enterprise Intermediate Goods Input}

The government implements environmental protection regulations and imposes pollution discharge fees on enterprises; the actual profits of enterprises decrease. To obtain greater market share and profits, enterprises must increase product competitiveness, increase the number of intermediate products, and increase the added value of products and the quality of export products. To verify this mechanism, the logarithm of the intermediate product input of our enterprise is put into the regression. The detailed results are shown in Table 10. The regression results in Column (1) show that the DID regression coefficient is positive and significant at the level of $1 \%$, indicating that the enhancement of government environmental regulations has significantly promoted the increase in the input of intermediate products of enterprises, confirming the content of our mechanism analysis. Furthermore, according to the enterprise production chain process, the input of intermediate products involves transportation costs and upstream and downstream relationships and is also closely related to geographic location. To verify the influence of regional heterogeneity on intermediate inputs, we divide the sample into western regions and nonwestern regions. Areas are tested, and the review results are shown in Columns (2) and (3) of Table 10. Although the regression results are all positive, the western region is not significant, while the nonwestern region is significant at the $1 \%$ level. This shows that the mechanism of environmental regulation in the western region is not obvious, but in the eastern and central regions, it has significantly promoted enterprises to increase investment in intermediate products and increase the added value of enterprises and the quality of export products. This finding is of great significance for improving improving the infrastructure and business environment in the western region.

\section{Table 9}

Analysis of the Input Mechanism of Enterprise Intermediate Goods

\begin{tabular}{cccc}
\hline Variable & All & Western & Nonwestern \\
& $(1)$ & $(2)$ & $(3)$ \\
\hline Treat*post & $0.0622^{* * *}$ & 0.0236 & $0.0522^{* * *}$ \\
Control variables & $(0.0177)$ & $(0.0766)$ & $(0.0181)$ \\
Individual fixed effect & YES & YES & YES \\
Time fixed effect & YES & YES & YES \\
Observations & YES & YES & YES \\
R-squared & 28203 & 1284 & 18845 \\
& 0.94 & 0.95 & 0.94 \\
\hline
\end{tabular}

Notes: *,*, and *** indicate statistical significance at the $10 \%, 5 \%$, and $1 \%$ levels, respectively. The individuallevel clustered standard errors are reported in parentheses.

\section{Conclusion}

Environmental protection requires effective environmental regulation policies. This study takes the pollution tax as a "top-down" environmental regulation to protect the environment, and explores how the pollution tax affects the quality of export products. In a highly concentrated country such as China, The "top-down" environmental regulation is often more effective, so the implementation of pollution tax has a greater impact on the production activities of enterprises. We collected data on enterprise pollution data from 2001 to 2008, matches them with the enterprise customs data and uses DID method to identify the impact of environmental regulation on product export quality. 
Our findings show that the government' s environmental regulations have significantly improved the quality of export products, and this conclusion is still valid after a series of robustness tests. Further analysis shows that the increase in the quality of export products originating from the regulated areas can be attributed to enterprise innovation and an increase in the input of intermediate products. Our results also show that the central government's environmental policy can realize the double dividend of economic development and environmental protection.

Environmental regulations on the quality of export products of enterprises shows obvious heterogeneity among enterprises with different ownerships and different locations. This shows that environmental regulations should be adapted to local conditions to allow and encourage governments to formulate environmental regulations suitable for the development of the region. Meanwhile, the government should encourage and promote the free flow of factor resources across regions, and provide maximum convenience for exports, and ultimately achieve high-quality development.

\section{Acknowledgements}

This study was sponsored jointly by a grant from the National Natural Science Fund of China (71973090) and the Fundamental Research Funds for the Central Universities (2017110136).

\section{Ethical approval}

No animal or human parts were used in this study. And the manuscript has not been published elsewhere and that it has not been submitted simultaneously for publication elsewhere.

\section{Consent to participate}

We the authors (author and co-authors) agreed to participate in this study without compulsion. This is a voluntary consent to participate in this research and we do agree on with everything in the manuscript.

\section{Consent to publish}

We have read the authors guide, rules and ethics for publication in Environmental Science and Pollution Research. All authors agree for the manuscript to be published in Environmental Science and Pollution Research.

\section{Availability of data and materials}

The datasets used during the current study are available from the corresponding author on reasonable request.

\section{Competing interest}

All authors have no conflict of interest with respect to our work being published in Environmental Science and Pollution Research.

\section{Author Contribution}

Haoyu Kuang : Conceptualization, Methodology, Software, Data curation, Writing - original 
561 Data curation, Writing - original draft, Writing- Reviewing and Editing.

\section{ORCID iD}

Yunjun Xiong 9 https://orcid.org/0000-0001-7823-8121

\section{Appendix A. Variable descriptions}

\section{Table A}

Variable descriptions and data sources.

\begin{tabular}{|c|c|c|}
\hline Variable & Variable name & Data descriptions and Source \\
\hline quality & $\begin{array}{l}\text { Enterprise export } \\
\text { product quality }\end{array}$ & Equation (5) \\
\hline size & Enterprise size & Logarithm of total assets \\
\hline $\ln \mathrm{L}$ & Number of employees & Logarithm of the number of employees \\
\hline age & Enterprise age & Current year minus year of business opening \\
\hline $\operatorname{lnkl}$ & Capital concentration & $\begin{array}{c}\text { Logarithm of (Total fixed assets/number of } \\
\text { employees) }\end{array}$ \\
\hline lev & Assets and liabilities & Total corporate liabilities/total corporate assets \\
\hline finance & Financing constraints & Interest expense/fixed assets \\
\hline sub & $\begin{array}{l}\text { Government subsidy } \\
\text { intensity }\end{array}$ & Government subsidies/total sales \\
\hline profit & Corporate profit margin & Total profit/total corporate assets \\
\hline $\mathrm{kc}$ & Capital output ratio & Fixed assets/Gross industrial output value \\
\hline lnwage & Per capita salary & $\begin{array}{c}\text { Logarithm of (Total wages payable/number of } \\
\text { employees) }\end{array}$ \\
\hline
\end{tabular}

\section{References}

Boubakri N, Cosset J (2008) Saffar W. Political connections of newly privatized firms. Journal of corporate finance, 14(5), 654-673.

Christainsen G, Haveman R (1981) Public Regulations and the Slowdown in Productivity Growth. American Economic Review, 71(2), 320-325.

Cao Y, Liu J, Yu Y, Wei G (2020) Impact of environmental regulation on green growth in China's manufacturing industry-based on the Malmquist-Luenberger index and the system GMM model. Environmental Science and Pollution Research, 27:41928-41945.

Cole M, Elliottrjr Shimamoto K (2005) Why the grass is not always greener: the competing effects of environmental regulations and factor intensities on US specialization. Ecological Economics, 54(1), 95-109.

Deily M, Grey W (1991) Enforcement of Pollution Regulations in a Declining Industry. Journal of Environmental Economics and Management, 21(3), 260-274.

Ederington J, Minier J (2003) Is environmental policy a secondary trade barrier? an empirical analysis. Canadian Journal of Economics/revue Canadienne Déconomique, 36(1), 137-154.

Ghanem D, Zhang J (2014) 'Effortless Perfection:' do Chinese cities manipulate air pollution data? Journal of Environmental Economics and Management, 68(2), 203-225.

Goldsmith J (1961) Urban Air Conservation. Bulletin of the Atomic Scientists, 376.

Grey W, Shadbegian R (1998) Environmental Regulation, Investment Timing and Technology Choice. The Journal of Industrial Economics, 46(2), 235-256. 
Grey W, Shadbegian R (2014) Do EPA Regulations Affect Labour Demand? Evidence from the Pulp and Paper Industry. Journal of Environment Economics and Management, 68(1), 188-202.

Hallak J, Sivadasan J (2013) Product and Process Productivity: Implications for Quality Choice and Conditional Exporter Premia. Journal of International Economics, 91 (1), 53-67.

Hering L, Poncet S (2014) Environmental policy and exports: evidence from Chinese cities. Journal of Environmental Economics and Management, 68(2), 296-318.

Homsy G, Liu Z, Warner M (2019) Multilevel governance: framing the integration of top-down and bottom-up policy-making. International Journal of Public Administration, 42(1), 1-11.

Jacobson L, LaLonde R, Sullivan D (1993) Earnings Losses of Displaced Workers. American Economic Review, 83(4),685-709.

Jefferson G, Tanaka S, Yin W (2013) Environmental Regulation and Industrial Performance: Evidence from Unexpected Externalities in China. SSRN Electronic Journal.

Jorge M, Madueno J, Martinez M (2015) Competitiveness and Environmental Performance in Spanish Small and Medium Enterprises: Is There a Direct Link? Journal of Cleaner Production, 101, 26-37.

Khandelwal A (2010) The Long and Short of Quality Ladders. Review of Economic Studies, 77 (4), 1450-1476.

Khandelwal A, Schott P, Wei S (2013) Trade Liberalization and Embedded Institutional Reform: Evidence from Chinese Exporters. American Economic Review, 103(6), 2169-2195.

Levinson A, Taylor M (2008) Unmasking the Pollution Haven Effect. International Economic Review, 49(1), 223254.

Li H, Zhou L A (2005) Political turnover and economic performance: The incentive role of personnel control in China. Journal of Public Economics, 89, 1743-1762.

Liu Y, Mao J (2019) How Do Tax Incentives Affect Investment and Productivity? Firm-Level Evidence from China. American Economic Journal: Economic Policy, 11(3), 261-291.

Melitz M (2003) The impact of trade on intraindustry reallocations and aggregate industry productivity. Econometrica, 71(6), 1695-1725.

Mian A, Sufi A (2014) What Explains the 2007-2009 Drop in Employment? Econometrica, 82(6), 2197-2223.

Nevo A (2001) Measuring Market Power in the Ready-to-Eat Cereal Industry. Econometrica, 69(2), 307-342.

Peuckert J (2014) What Shapes the Impact of Environmental Regulation on Competitiveness? Evidence from Executive Opinion Surveys. Environmental Innovation and Societal Transitions, 10, 77-94.

Porter M, Linde C (1995) Towards a New Conception of the Environment-Competitiveness Relationship. The Journal of Economic Perspectives, 9(4), 97-118.

Qing L, Lu Y (2015) Firm investment and exporting: Evidence from China's value-added tax reform. Journal of International Economics, 97(2), 392-403.

Sam A, Zhang X (2020) Value relevance of the new environmental enforcement regime in China. Journal of Corporate Finance, 62.

Wang W, Sun X, Zhang M (2021) Does the central environmental inspection effectively improve air pollution?-An empirical study of 290 prefecture-level cities in China. Journal of Environmental Management, 286:112274.

Wu J, Deng Y, Huang J, Morck R, Yeung B (2014) Incentives and Outcomes: China's Environmental Policy. Capitalism and Society, 9(1), 1-41.

Zhong S, Xiong Y, Xiang G (2021) Environmental regulation benefits for whom? Heterogeneous effects of the intensity of the environmental regulation on employment in China. Journal of Environmental Management, $281,111877$.

Zhou K, Gao G, Zhao H (2017) State ownership and firm innovation in China: an integrated view of institutional and efficiency logics. Administrative Science Quarterly, 62(2), 375-404. 